\title{
A quantas anda a gestão de recursos humanos no setor público brasileiro? Um ensaio a partir das (dis)funções do processo de recrutamento e seleção - os concursos públicos
}

\author{
Fernando de Souza Coelho \\ Universidade de São Paulo (USP) \\ Isabela de Oliveira Menon \\ Universidade de São Paulo (USP)
}

Este artigo é um balanço sobre a gestão de recursos humanos (GRH) no setor público brasileiro, considerada como área funcional da administração pública e, portanto, como uma das dimensões para uma política pública de gestão. Após algumas provocações na introdução que problematizam a gestão de pessoas nos governos e nas organizações públicas no Brasil, o artigo analisa o processo de recrutamento e seleção, baseado no instituto do concurso público, como uma proxy das disfunções na GRH - assinalada pelo exacerbado foco jurídico e por falhas de natureza gerencial. Trata-se de um ensaio que abaliza a existência de um círculo vicioso do concurso público no país, argumenta sobre o anacronismo do modelo vigente dos certames e aponta alguns problemas oriundos da desintegração entre os subsistemas de ingresso no serviço público.

Palavras-chave: gestão de pessoas, concurso público, recrutamento de pessoal, seleção de pessoal, administração pública - Brasil

[Artigo recebido em 4 de junho de 2018. Aprovado em 13 de novembro de 2018.] 
¿Cómo está la Gestión de Recursos Humanos en el Sector Público Brasileño? un ensayo basado en las (dis)funciones del proceso de reclutamiento y selección - los concursos públicos.

Este artículo es una reseña sobre la gestión de recursos humanos (GRH) en el sector público brasileño, considerada como área funcional de la administración pública y, por lo tanto, como una de las dimensiones para una política pública de gestión. Después de algunas provocaciones en la introducción que problematizan la gestión de personas en los gobiernos y en las organizaciones públicas en Brasil, el artículo analiza el proceso de reclutamiento y selección, basado en el instituto del concurso público, como una proxy de las disfunciones en la GRH - señalada por el exacerbado foco jurídico y por fallas de naturaleza gerencial. Se trata de un ensayo que abaliza la existencia de un círculo vicioso del concurso público en el país, argumenta sobre el anacronismo del modelo vigente de los certámenes y apunta algunos problemas oriundos de la desintegración entre los subsistemas de ingreso en el servicio público.

Palabras clave: gestión de personas, concurso público, reclutamiento de personal, selección de personal, administración pública - Brasil

How is the Human Resources Management in the Brazilian Public Sector? an essay based on the (dys)functions of the recruitment and selection process - the civil service examinations

This article reviews the human resources management (HRM) of the Brazilian public sector as a functional area of public administration. The study begins by problematizing the management of public organizations and personnel in Brazil. Next, it further analyzes the recruitment and selection process, based on civil service examinations, as a proxy for the dysfunctions in HRM - marked by exacerbated legal focus and managerial failures. The essay emphasizes the existence of a civil service examinations vicious circle in the country, arguing over an anachronism of the current model of events and pointing out to problems arising from the disintegration of the subsystems of entry amid the public service.

Keywords: management, public recruitment, recruitment of staff, selection of personnel, public administration - Brazil management, public recruitment, recruitment of staff, selection of personnel, public administration - Brazil 


\section{Introdução}

Em 2005, em um artigo que analisou os resultados do Programa Nacional de Apoio à Modernização da Gestão e do Planejamento dos Estados e do Distrito Federal (PNAGE) ${ }^{1}$, Abrucio afirmara:

(...) o maior problema dos estados está na área de recursos humanos. Primeiro, porque a precariedade da informação é brutal diante da importância do RH para o restante da administração pública. (...) as informações revelam a falta de um quadro capacitado o suficiente para suas funções, ausência de pessoal em diversas áreas, má alocação em outras e envelhecimento da força de trabalho. Tal situação é um empecilho para a implementação das políticas públicas e até mesmo para a realização de reformas administrativas, pois o elemento humano é essencial para transformar a gestão pública (ABRUcıo, 2005, p. 410-411).

Decorridos 15 anos do diagnóstico do PNAGE sobre a ausência de política de recursos humanos nos estados e no Distrito Federal, ressurge a questão, desta vez, para todos os níveis de governo do país: a quantas anda a gestão de recursos humanos (GRH) no setor público brasileiro? No quadriênio 2015-2018, o agravamento da crise fiscal recolocou na agenda governamental o debate sobre os ajustes e/ou reformas das despesas de pessoal - isto é, a folha de pagamento e o regime de previdência do funcionalismo público. Todavia, além do rol de problemas macroestruturais na seara da economia dos recursos humanos no Estado brasileiro, empoderados politicamente e visíveis socialmente, temos um elenco de questões da GRH como uma das áreas-meio da gestão pública - na acepção administrativo-institucional -, que, do mesmo modo, necessitam ser (re)pensadas para a modernização da administração pública nacional.

São questões que, embora não estejam no cerne das narrativas políticas e das pautas midiáticas sobre as reformas prementes no Brasil, são fulcrais para a boa gestão da "casa de máquina" no Estado e, por conseguinte, para a qualidade das políticas públicas e o delivery dos serviços públicos. Eis algumas indagações

\footnotetext{
${ }^{1}$ Desenhado no biênio 2001-2002, o PNAGE teve início a partir do primeiro semestre de 2003, com a definição de uma metodologia de assistência técnica aos estados e Distrito Federal promovida pelo Ministério do Planejamento, Orçamento e Gestão. O Conselho Nacional de Secretários de Administração (Consad), o Conselho Nacional de Secretários de Planejamento (Conseplan), o Banco Interamericano de Desenvolvimento (BID) e a Caixa Econômica Federal (CEF) atuaram como parceiros no desenvolvimento do programa. Os trabalhos envolveram, inicialmente, diversos diagnósticos nas unidades da Federação sobre: capacidade de planejamento e gestão de políticas públicas; capacidade de administração de recursos humanos; status da modernização da estrutura organizacional e de seus processos administrativos; uso de mecanismos de transparência administrativa e de comunicação social; e status da modernização da gestão de informação e integração de sistemas.
} 
da GRH no setor público, na atualidade: como recrutar e selecionar indivíduos vocacionados para o serviço público em vez dos concurseiros? Como alinhar o treinamento e o desenvolvimento de recursos humanos na gestão pública com a estratégia governamental? Como redistribuir a força de trabalho entre as áreas e integrar cargos/carreiras fragmentados? Como estruturar equipes de trabalho comprometidas com programas/projetos em uma organização do trabalho tipicamente - neotaylorista e sem incentivos pecuniários? Como ordenar a política de recursos humanos do governo e das unidades centrais de recursos humanos com a GRH descentralizada dos órgãos públicos? Como implantar uma gestão do desempenho que não se limite à aplicação de avaliações formais sem efeito?

A resposta para muitas dessas perguntas passa, necessariamente, pela calibragem da histórica abordagem jurídica do funcionamento dos departamentos de pessoal com um upgrade da racionalidade e das práticas de gestão de recursos humanos nos governos e nas organizações públicas. Segundo Marconi (2005).

O papel [de longa data] desempenhado pela área de $\mathrm{RH}$ dos governos [e das organizações públicas no Brasil] enfatiza duas funções clássicas: o processamento de tarefas administrativas relacionadas aos pagamentos e aos benefícios, bem como a proposição de regras e regulamentos (...), ficando conhecida como departamento de pessoal [ou DP]. De um modo geral, a área acaba sendo gerenciada de forma reativa: uma área que apenas responde a demandas de outras áreas e que parecem estar fora de seu controle (...). [Enfim], uma gestão de problemas, emergencialista, que trabalha constantemente para apagar incêndios (MARCoNI, 2005, p. 330-331).

Com essa configuração nitidamente operacional e de estilo balcão de atendimento, a GRH no setor público é - tradicionalmente - uma área-meio com falta de policy (orientação estratégica) e programas táticos-gerenciais relegados ao segundo plano, além de historicamente ser sobrepesada pelo legalismo e o corporativismo, obstaculizando a reforma administrativa das suas diretrizes e funcionalidades.

Entretanto, pela metáfora do copo meio vazio, meio cheio, a GRH no setor público brasileiro pode, positivamente, ser analisada pelas inovações incrementais e silenciosas que ocorrem nos governos e nas organizações públicas e se caracterizam como boas práticas pontuais na gestão de pessoas. Por estarem espraiadas como protótipos e experiências difusas que não se aglutinam sob o guarda-chuva explícito ou formal de uma reforma, essas ações nem sempre são percebidas em sua magnitude. Obviamente que existe um conjunto de esforços levados a cabo e bom termo por organizações dos três níveis de governo e dos três poderes e que indicam avanços na GRH na máquina pública. Por esse ângulo, o banco de dados de 10 anos do Congresso Consad de Gestão Pública, com um acervo de cerca de 300 
trabalhos de $\mathrm{GRH}^{2}$ (incluindo experimentos inovadores, práticas bem construídas e casos de referência), ilustra tal processo de melhoria contínua e a existência de uma comunidade de prática.

Em um levantamento realizado por Levy, Coelho e Menon (2017), apresentado durante o X Congresso Consad de Gestão Pública, esses autores analisaram e classificaram os trabalhos de GRH do referido banco de dados. Dos 269 trabalhos apresentados em nove edições do evento (2008-2016), um terço versa sobre gestão por competências e T\&D (treinamento e desenvolvimento) no setor público vide a Tabela 1. Algo explicado, provavelmente, pela agenda da Política Nacional de Desenvolvimento de Pessoal (PNDP), criada pelo Decreto no 5.707/2006 no Governo Federal, e pela difusão das escolas de governo no Brasil desde a Emenda Constitucional (EC) no 19/1998. Reclassificando os trabalhos dos 15 temas da Tabela 1 entre os sete subsistemas de GRH de Longo (2007), observa-se que a gestão do desenvolvimento (promoções, capacitações e processos de formação e aprendizagem) e a organização do trabalho (desenho de postos de trabalho e definição de perfis ocupacionais) correspondem a quase $60 \%$ dos artigos/relatos do evento - vide a Tabela 2.

Tabela 1 - Classificação dos trabalhos de GRH do Congresso Consad, por tema

\begin{tabular}{lccccccccccc}
\hline Tema / Ano & 2008 & 2009 & 2010 & 2011 & 2012 & 2013 & 2014 & 2015 & 2016 & Total & $\%$ \\
\hline $\begin{array}{l}\text { Competências } \\
\text { Capacitação }\end{array}$ & 2 & 6 & 7 & 9 & 5 & 9 & 3 & 6 & 4 & 51 & $19,0 \%$ \\
$\begin{array}{l}\text { (T\&D) } \\
\begin{array}{l}\text { Estratégia de } \\
\text { RH }\end{array}\end{array}$ & 0 & 0 & 5 & 6 & 9 & 4 & 2 & 1 & 2 & 29 & $10,8 \%$ \\
\hline $\begin{array}{l}\text { Cargos e } \\
\text { carreiras }\end{array}$ & 0 & 1 & 5 & 1 & 6 & 4 & 6 & 4 & 1 & 28 & $10,4 \%$ \\
$\begin{array}{l}\text { Desempenho } \\
\begin{array}{l}\text { Sistemas de } \\
\text { RH }\end{array}\end{array}$ & 1 & 1 & 2 & 8 & 2 & 3 & 0 & 3 & 1 & 21 & $7,8 \%$ \\
\hline $\begin{array}{l}\text { Clima e } \\
\text { cultura }\end{array}$ & 1 & 1 & 0 & 5 & 2 & 0 & 4 & 0 & 1 & 14 & $5,2 \%$ \\
\hline $\begin{array}{l}\text { Ingresso } \\
\text { Previdência }\end{array}$ & 0 & 0 & 2 & 0 & 0 & 3 & 2 & 1 & 3 & 11 & $4,1 \%$ \\
\hline
\end{tabular}

\footnotetext{
${ }^{2} \mathrm{O}$ banco de dados do Congresso Consad de Gestão Pública, incluindo os trabalhos de todas as áreas do evento, totaliza aproximadamente 1500 artigos/relatos apresentados nas suas dez edições entre 2008-2017. O acesso é livre e aberto pelo site: http://banco.consad.org.br/.
} 


\begin{tabular}{lccccccccccc}
\hline Liderança & 1 & 1 & 0 & 0 & 3 & 2 & 0 & 2 & 0 & 9 & $3,3 \%$ \\
\hline $\begin{array}{l}\text { Remuneração } \\
\text { Planej./Dim. }\end{array}$ & 1 & 3 & 2 & 0 & 0 & 3 & 0 & 0 & 0 & 9 & $3,3 \%$ \\
$\begin{array}{l}\text { de RH } \\
\text { Saúde do }\end{array}$ & 0 & 0 & 0 & 0 & 5 & 1 & 2 & 0 & 0 & 8 & $3,0 \%$ \\
$\begin{array}{l}\text { servidor } \\
\begin{array}{l}\text { Inovações em } \\
\text { GRH }\end{array}\end{array}$ & 1 & 1 & 2 & 0 & 0 & 1 & 0 & 0 & 0 & 5 & $1,9 \%$ \\
$\begin{array}{l}\text { Meritocracia } \\
\text { Total }\end{array}$ & 0 & 1 & 0 & 0 & 1 & 3 & 0 & 0 & 0 & 5 & $1,9 \%$ \\
\hline
\end{tabular}

Fonte: Levy, Coelho e Menon (2017).

\section{Tabela 2-Classificação dos trabalhos de GRH do Congresso Consad, por subsistema}

\begin{tabular}{|c|c|c|c|c|c|c|c|c|c|c|c|}
\hline $\begin{array}{l}\text { Subsistema / } \\
\text { Ano }\end{array}$ & 2008 & 2009 & 2010 & 2011 & 2012 & 2013 & 2014 & 2015 & 2016 & Total & $\%$ \\
\hline $\begin{array}{l}\text { Gestão do } \\
\text { desenvolvimento }\end{array}$ & 4 & 11 & 9 & 13 & 10 & 23 & 14 & 10 & 7 & 101 & $37,5 \%$ \\
\hline $\begin{array}{l}\text { Organização do } \\
\text { trabalho }\end{array}$ & 1 & 3 & 8 & 7 & 15 & 10 & 4 & 4 & 7 & 59 & $21,9 \%$ \\
\hline $\begin{array}{l}\text { Gestão da } \\
\text { remuneração }\end{array}$ & 1 & 5 & 7 & 1 & 10 & 8 & 7 & 7 & 1 & 47 & $17,5 \%$ \\
\hline $\begin{array}{l}\text { Gestão das } \\
\text { relações } \\
\text { humanas e } \\
\text { sociais }\end{array}$ & 1 & 1 & 0 & 5 & 7 & 1 & 6 & 0 & 1 & 22 & $8,2 \%$ \\
\hline $\begin{array}{l}\text { Gestão do } \\
\text { desempenho }\end{array}$ & 1 & 1 & 2 & 8 & 2 & 3 & 0 & 3 & 1 & 21 & $7,8 \%$ \\
\hline $\begin{array}{l}\text { Gestão do } \\
\text { emprego }\end{array}$ & 0 & 0 & 2 & 0 & 0 & 3 & 2 & 1 & 3 & 11 & $4,1 \%$ \\
\hline $\begin{array}{l}\text { Planejamento } \\
\text { de recursos } \\
\text { humanos }\end{array}$ & 0 & 2 & 0 & 0 & 1 & 0 & 1 & 2 & 2 & 8 & $3,0 \%$ \\
\hline Total & 8 & 23 & 28 & 34 & 45 & 48 & 34 & 27 & 22 & 269 & $100 \%$ \\
\hline
\end{tabular}

Fonte: Levy, Coelho e Menon (2017), empregando os subsistemas de Longo (2007).

Considerando, adicionalmente, as abordagens, os objetos e os processos desprovidos de debate nos trabalhos de GRH do Congresso Consad no período, os autores identificaram: a carência de trabalhos com abordagem do comportamento organizacional (ethos e cultura, comprometimento/motivação, formação de equipes e sentidos do trabalho) no setor público3; a escassez de trabalhos que tenham

\footnotetext{
${ }^{3}$ Para um trabalho com tal abordagem na literatura nacional, ver, por exemplo, o artigo de Rodrigues et al. (2017).
} 
como objeto de estudo as burocracias do nível da rua ${ }^{4}$; e o déficit de trabalhos que discutem o processo de recrutamento e seleção nos governos pelo instituto do concurso público (LeVY; CoelHo; MenON, 2017).

A carência da abordagem do comportamento organizacional deriva dos paradigmas burocrático e gerencialista da GRH no setor público brasileiro, de orientação formal e estruturalista, que minimizam recorrentemente as variáveis socioculturais e os aspectos relacionais nas organizações públicas. A escassez de trabalhos sobre a burocracia do nível da rua, prestadora de serviços públicos para os cidadãos, é interpretada pela sua relativa desvalorização social na estrutura hierárquica do serviço público; geralmente, os cargos que são objetos de estudo perfazem a burocracia de médio escalão e são inerentes às carreiras do ciclo de gestão. E o déficit de trabalhos sobre concursos públicos deve-se à primazia da lógica jurídico-legal na seleção de pessoal no serviço público; no caso, é como se o instituto jurídico, rígido e estanque, fosse impermeável aos instrumentos de GRH. Salientemos que as reformas de segunda geração na administração pública nacional avançaram em diversos fronts da gestão governamental, como observado neste século nos processos de governo eletrônico, sistemas de atendimento ao cidadão e licitações. Sem embargo, os ajustes e mudanças modernizantes e/ou desburocratizantes ainda não alcançaram, plenamente, os processos de seleção e recrutamento no setor público.

Um debate que urge, por exemplo, é como o modelo de gestão por competência - diferente do padrão de qualificação - tem se justaposto no subsistema de seleção de pessoal no serviço público brasileiro. No instituto do concurso público, uma das interrogações é como transmutar as atribuições/funções do cargo previstas em edital em competências individuais passíveis de serem aferidas nas provas dos certames. Ou, em uma perspectiva mais ampla, como inovar nos mecanismos de ingresso no serviço público?

Neste artigo, para se refletir sobre a gestão de recursos humanos no setor público brasileiro no momento hodierno, analisar-se-á o processo de recrutamento e seleção. Jogando luz na "porta de entrada" convencional, este ensaio pressupõe o instituto do concurso público como uma proxy das disfunções na GRH no serviço público - assinalada pelo exacerbado foco jurídico e por falhas de natureza gerencial que distorcem as etapas de ingresso.

Assim, na sequência, a seção 2 abaliza a existência de um círculo vicioso do concurso público no Brasil, argumenta sobre o anacronismo do modelo vigente dos certames e aponta os problemas oriundos da desintegração entre os subsistemas

${ }^{4}$ Para a ilustração de um trabalho com tal objeto de estudo em âmbito doméstico, ver a tese de doutorado de Lotta (2010). 
de ingresso no serviço público. A seção 3, à guisa de conclusão, apresenta as considerações finais - no caso, uma síntese da problemática atual da GRH no Estado brasileiro e algumas implicações gerenciais para se repensar o instituto do concurso público no país.

\section{O concurso público como proxy das disfunções na GRH no serviço público ${ }^{5}$}

No Brasil o concurso público é o instituto jurídico que representa a noção de mérito na seleção de pessoal na administração pública, baseado no ordenamento constitucional - com a consagração de seus princípios - para o preenchimento de cargo ou emprego público. Diversas são as conceituações quanto ao instituto do concurso público dadas pelos juristas do Direito Administrativo no país, as quais variam em um continuum entre definições objetivas, baseadas nos princípios da Constituição Federal (CF) de 1998; e definições subjetivas, fundadas em interpretações referentes aos atos que consubstanciam os certames em um procedimento administrativo.

Entre as definições objetivas, Meirelles (1999) enuncia o concurso público como:

(...) o meio técnico posto à disposição da administração pública para obterse moralidade, eficiência e aperfeiçoamento do serviço público e, ao mesmo tempo, propiciar igual oportunidade a todos interessados que atendam aos requisitos da lei, fixados de acordo com a natureza e a complexidade do cargo ou do emprego, consoante determina o artigo 37, inciso II, da Constituição Federal (Meirelles, 1999, p. 419).

Concernente às definições subjetivas, Carvalho Filho (2007) concebe o concurso público como:

(...) o procedimento administrativo que tem por fim aferir as aptidões pessoais e selecionar os melhores candidatos para acesso aos cargos e empregos públicos. Na aferição pessoal, o Estado verifica a capacidade intelectual, física e psíquica de interessados em ocupar funções públicas e no aspecto seletivo são escolhidos aqueles que ultrapassam as barreiras opostas no procedimento, obedecida sempre a ordem de classificação (CARVALHo FILHO, 2007, p. 554).

\footnotetext{
${ }^{5}$ Esta seção é uma versão modificada e atualizada de capítulo intitulado Repensando os concursos públicos no Brasil: subsídios para discussão à luz da gestão de pessoas no setor público, de autoria de Fernando de Souza Coelho - primeiro autor deste artigo -, integrante do livro Uma nova gestão é possível. A obra foi organizada por Ivany Bassotti, Sandra Pinto e Thiago Santos, e publicada pelas Edições Fundap em 2015. Como a impressão da primeira edição está esgotada, e não há como ocorrer uma reimpressão pela extinção da Fundap, o texto do capítulo foi ajustado para este artigo como unidade de análise da GRH no serviço público do país - no caso, o processo de recrutamento e seleção.
} 
Considerando esses dois conceitos jurídico-administrativistas relativos a concurso público, independente de o primeiro alicerçar-se em uma definição objetiva e o segundo assentar-se em uma definição subjetiva, ambos asseveram o desígnio de tal instituto como: (a) direito de igualdade entre os cidadãos no acesso aos cargos e empregos públicos, em contraposição às discriminações e aos favorecimentos; e (b) busca da garantia da seleção de candidatos que estejam aptos e sejam capacitados para o exercício de uma função pública, em prol de qualidade na prestação dos serviços públicos e na provisão das políticas públicas.

Todavia, ainda que a doutrina dos concursos públicos se fundamente, sobretudo, nos princípios de impessoalidade e da eficiência tal como exposto, muitos de seus processos e resultados são disfuncionais na administração pública brasileira nas últimas décadas. Com a retomada da contratação de funcionários públicos no país a partir de meados dos anos 1990 na União, e com o crescimento e a diversificação dos certames nos três níveis de governo - após o ajuste fiscal - nos anos $2000^{6}$, eclodiram várias disfuncionalidades nos concursos públicos, sobretudo no nível subnacional, marcadas por deformidades de planejamento, irregularidades de organização e anormalidades na finalidade em organizações públicas de alguns estados e de muitos municípios.

Obviamente que, em qualquer estrutura social racional-legal, sempre é observável (e, em alguns casos, tolerável) um determinado grau ou nível de disfunção. Afinal, como nos ensina Merton (1959), as organizações burocráticas apresentam, comumente, algumas consequências imprevistas ou indesejadas oriundas das contradições entre a prescrição formal das estruturas/processos e o arranjo informal dos comportamentos administrativos, quer dizer, as disfunções burocráticas. Contudo, no que se refere ao instituto do concurso público no Brasil, alguns autores/estudos evidenciam numerosas imperfeições e, por conseguinte, atestam a crise desse modelo de seleção de pessoal no setor público, urgindo a sua reforma administrativa e/ou inovações na sua aplicação.

Muitos juristas, por exemplo, amparados em casos de concursos públicos que desobedecem aos princípios constitucionais e violam o objetivo fundamental de sua realização, bem como constatando a recorrente judicialização dos certames e sua jurisprudência, defendem a regulamentação por uma lei nacional dos concursos

\footnotetext{
${ }^{6}$ Comparando o número de funcionários públicos no Brasil, nos três níveis de governo, no intervalo entre 1995 e 2015 , observa-se um crescimento de $57 \%$. Na União a força de trabalho aumentou de cerca 1,4 milhões para aproximadamente 2,1 milhões de funcionários. O funcionalismo público estadual, por sua vez, manteve em torno de 3,3 milhões de funcionários no período. A gestão pública municipal ampliou, significativamente, o quadro de pessoal de 2,9 milhões para 6,5 milhões de funcionários, resultado das suas competências na Constituição Federal de 1988 e da descentralização das políticas públicas (BOLETIM ESTATíSTICO DE PESSOAL/MINISTÉRIO DO Planejamento, 2015; Munic e Estadic/IBge, 2015).
} 
públicos. Em linhas gerais, o argumento é que as diretrizes da Constituição Federal são insuficientes para normatizar os certames. Ilustrativamente, Sousa (2011, p. 119), em sua dissertação de mestrado apoiada na doutrina de Márcio Barbosa Maia e Ronaldo Pinheiro de Queiroz sobre o regime jurídico dos concursos públicos e seu controle jurisdicional, afirma que "a ausência de regras claras sobre as etapas procedimentais dos certames, os prazos, as condições legais para sua deflagração, a constituição das bancas examinadoras, a elaboração dos editais, entre outros (...)" são hiatos para um ordenamento jurídico infraconstitucional dos concursos públicos.

Nesse caso, a crítica ao modelo de concursos públicos refere-se às disfunções burocráticas de arbitrariedade nos processos de seleção de pessoal e, principalmente, à insegurança jurídica para os candidatos pela ausência de uma legislação específica e/ou padronizada. Tal debate aventa regras para os concursos públicos que norteiem os direitos e deveres dos candidatos (e dos aprovados), da organização pública contratante, das instituições que realizam a prova e das bancas avaliadoras. Concretamente, algo que regulamente o artigo 37, inciso II, da Constituição Federal (CF), estabelecendo uma norma intermediária entre os princípios jurídicos aplicáveis aos concursos públicos e os editais que regem os certames.

No rol de imprecisões que requerem normatização, com jurisprudência nos tribunais, encontram-se: (a) a estipulação do prazo de divulgação do edital; (b) a convenção dos atos de interposição de recursos e de anulação de questões nas provas; (c) a apresentação de diploma na inscrição ou posse; (d) o direito do aprovado à nomeação dentro do número de vagas previstas em edital; (e) a preterição de candidato aprovado, dentro do prazo de validade do certame, pela contratação de mão de obra precária para o cargo; e (e) a aplicação de concurso público para cadastro de reserva.

Desde meados da primeira década dos anos 2000, no bojo da realização de inúmeros concursos públicos no Brasil com muitas judicializações, surgem iniciativas de projetos de lei no Congresso Nacional para o regramento dos concursos públicos na União. Dentre essas iniciativas, em 2010, desponta a tramitação do Projeto de Lei do Senado (PLS) no 74/2010, que, em 2013, após algumas emendas e uma audiência pública, teve um substitutivo aprovado, conhecido como Lei Geral dos Concursos Públicos ou Estatuto dos Concursos Públicos. Enviado para a apreciação da Câmara dos Deputados desde o segundo semestre de 2013 sob o PL no 6004/2013, o projeto de lei, no aguardo de votação em regime de prioridade, estipula alguns preceitos como: (a) a proibição de concursos públicos para a formação de cadastro de reserva; (b) a determinação do prazo mínimo de 90 dias entre a publicação 
do edital e a realização das provas; (c) o impedimento de que a instituição que realiza a prova delegue a organização para terceiros; (d) a previsão de indenização aos candidatos em caso de anulação do certame; e (e) o direito à nomeação de candidatos aprovados em concurso público, caso o órgão contrate temporários ou terceiros no decorrer do prazo de validade do certame para exercerem as funções previstas no edital.

Entretanto, imaginemos que o PL no 6004/2013 seja aprovado pela Câmara dos Deputados e que tal lei, de abrangência federal ${ }^{7}$, seja um parâmetro para que os estados e municípios editem legislações assemelhadas. Logo, as disfunções burocráticas do instituto do concurso público no país estariam plenamente resolvidas? Absolutamente, a resposta é não! Seria dirimida, sim, a insegurança jurídica dos concursos públicos e assegurado o direito dos candidatos, como defendem entidades como a Associação Nacional de Proteção e Apoio aos Concursos (Anpac), o Movimento pela Moralização dos Concursos (MMC) e a Associação Nacional dos Concurseiros (Andacom).

Enfim, nosso pressuposto é de que o aperfeiçoamento do modelo de concurso público como instituto jurídico para contratar as pessoas aptas e capacitadas para o serviço público depende, além de um upgrade do marco legal, de instrumentos de gestão de recursos humanos no setor público que estejam integrados e sejam compatíveis com o (novo) ideário de profissionalização da administração pública contemporânea.

\section{O círculo vicioso do concurso público no Brasil}

Em adição ao debate tradicional dos administrativistas para a melhoria do instituto jurídico do concurso público no Brasil, faz-se mister uma discussão sobre a modernização de seu modelo conforme o framework da gestão de recursos humanos no setor público. Essa abordagem não relativiza a importância da dimensão jurídico-legal em tal reflexão, mas a complementa com uma perspectiva de instrumentos gerenciais cabíveis à administração de pessoal nas organizações públicas.

Inclusive, algumas das questões que advêm da abordagem de gestão de recursos humanos no setor público para (re)pensar os concursos públicos no país são compartilhadas por alguns juristas, sejam do Direito Administrativo, sejam da Sociologia do Direito. Ademais, como a literatura sobre concursos públicos é

\footnotetext{
${ }^{7}$ A União não tem competência para legislar sobre normas relativas aos concursos públicos para as administrações públicas diretas, autárquicas e fundacionais dos estados e municípios. Seria necessário um projeto de emenda à Constituição (PEC) que incluísse tal competência para a União, o que ocorreu, por exemplo, com o instituto de licitações/contratos.
} 
incipiente na área de gestão de pessoas, nota-se que algumas das ideias que ecoam sobre a crise do modelo de concursos públicos - em adição ao marco legal procedem de acadêmicos do Direito.

Nesse sentido, uma contribuição nesta década é o estudo levado a cabo por um conjunto de pesquisadores da Fundação Getúlio Vargas do Rio de Janeiro (FGV-RJ) e da Universidade Federal Fluminense (UFF), intitulado Processos seletivos para a contratação de servidores públicos: Brasil, o país dos concursos?, sob a coordenação do Prof. Dr. Fernando de Castro Fontainha. O trabalho integrou o projeto Pensando o Direito, organizado pela Secretaria de Assuntos Legislativos (SAL), do Ministério da Justiça (MJ), com apoio do Programa das Nações Unidas para o Desenvolvimento (PNUD), e contém um acervo de investigações de enfoque interdisciplinar e de cunho empírico sobre temas atinentes ao melhoramento da máquina administrativa no Estado brasileiro, abrangendo, entre outros assuntos, os concursos públicos.

De caráter aplicado e abordando os concursos públicos no Brasil como matéria não estritamente jurídica, a investigação supracitada de Fontainha et al. (2013) levanta, de modo denodado, a hipótese de que os concursos públicos no país na última década foram “(...) organizados a partir de uma ideologia concurseira (...); [e concluem] que a crise do modelo [desse instituto jurídico] pede superação; da crise, não do modelo" (FONTAINHA et al., 2013, p. 371-373). Os autores se valem do neologismo concurseiro para caracterizar uma ideologia concurseira - em contraposição à ideologia acadêmica da burocracia organizacional e à ideologia profissional da burocracia profissional ${ }^{8}-$, na qual:

(...) a tônica fundamental das seleções de funcionários públicos é completamente autorreferenciada nas estratégias dos candidatos, nos discursos de legitimação, na forma de organização e no projeto institucional, o que acarreta enorme prejuízo de recursos financeiros e humanos para a Administração Pública (FontaINHA et al., 2013, p. 298).

\footnotetext{
${ }^{8}$ A burocracia organizacional, com grande tradição na França e na Alemanha, baseia-se em um recrutamento acadêmico que atrela o ingresso no serviço público à conclusão de cursos universitários específicos e/ou à realização de programas de formação em escolas de governo. No Brasil, um exemplo é a carreira de Especialista em Políticas Públicas e Gestão Governamental no Estado de Minas Gerais, cujo ingresso é condicionado à aprovação no vestibular e a realização do Curso Superior de Administração Pública (CSAP) ministrado pela Escola de Governo da Fundação João Pinheiro (EG-FJP/MG); outros exemplos são a carreira diplomática e as escolas militares de formação de oficiais nas forças armadas e na polícia militar. Já a burocracia profissional orientase pela experiência/treinamento profissional e pelo recrutamento aberto, desvinculados de um compromisso antecipado com a carreira no setor público. Tem forte institucionalização em países como Estados Unidos e Canadá. No Brasil, sua adoção é incipiente, permeando o debate mais recente sobre critérios para a nomeação de dirigentes públicos e formas alternativas de contratação de burocratas de médio escalão como programas de liderança pública, trainees e residência para ocupar cargos de Direção e Assessoramento (DAS) no setor público; para uma ilustração pela literatura, ver Lamelo et al (2017).
} 
A comunicação dessa pesquisa repercutiu de maneira ampla na imprensa nacional no triênio 2013-2015, visto que muitos dos seus achados confrontavam o senso comum sobre a contratação de funcionários públicos, bem como suas propostas de alterações no modelo de concurso público preconizavam inovações; desde novos critérios para taxas/formas/condições de inscrição, até novos parâmetros para a escolha de tipos de provas e a inclusão de habilidades nos instrumentos de avaliação, passando por novos métodos para escolha das bancas examinadoras e a exigência de formação inicial dos aprovados acoplada ao estágio probatório. De acordo com os proponentes, essas mudanças visam a “(...) frear radicalmente a ideologia concurseira" (FONTAINHA et al., 2013, p. 392), causando anomalias nos processos e, por conseguinte, nos resultados de seleção de pessoal na administração pública brasileira.

Reproduzida de forma maciça na práxis do concurso público no país, a ideologia concurseira captura não apenas os certames, mas todo o sistema envolto ao ingresso no serviço público, aprisionando, no limite, a própria (in)capacidade estatal de gerenciamento estratégico e/ou tático do sistema de recursos humanos e de seus subsistemas. Dentre os fenômenos derivados de tal lógica, assinalamse quatro ocorrências que se entrelaçam em uma espécie de círculo vicioso dos concursos públicos no Brasil.

A primeira ocorrência é a insuficiência ou ausência de um ethos de serviço público que abre espaço para o predomínio de uma retórica segundo a qual os concursos públicos invariavelmente recrutam e selecionam os indivíduos mais preparados e com maior aptidão para realizar as funções públicas. Essa crença coletiva em torno do instituto jurídico fomenta algumas disfuncionalidades nos certames ao enfatizar, em demasia, o direito dos indivíduos em detrimento dos aspectos substantivos da seleção de pessoal no setor público. Isto é, nas palavras de Fontainha et al. (2013, p. 293), os concursos públicos se postam na sociedade brasileira mais como "um efeito colateral de uma marcha pela igualdade" em combate ao modelo patrimonial e à gramática política do clientelismo. E, no esteio desse entendimento, o espírito dos certames reverbera o foco dos candidatos que, mormente, se transfiguram em concurseiros ${ }^{9}$.

\footnotetext{
${ }_{9}$ Salienta-se que os candidatos concurseiros se diferenciam dos candidatos concursandos. Os concurseiros, retratados no artigo de Albrecht e Krawulski (2011), são candidatos que a priori aspiram a estabilidade e salários - comparativamente - altos no setor público, independente da vocação para o trabalho e com obstinação pela aprovação em um primeiro certame. Já os concursandos, por sua vez, buscam por excelência realizar sua vocação no serviço público e encaram o concurso público como uma etapa pré-laboral, ou seja, uma condição sine qua non para a realização profissional.
} 
Enfim, a hegemonia do viés concurseiro no país tanto dissemina a noção de mérito circunscrita somente à aprovação e colocação nos certames, como bloqueia o pensamento em torno da modernização do modelo de concurso público e da adoção de formas alternativas de recrutamento e seleção no setor público baseadas nos legados da burocracia organizacional e profissional.

A segunda ocorrência é a indústria do concurso público, cujo elo principal são os cursinhos na modalidade presencial e a distância, alguns dos quais se transformam em cursos de pós-graduação lato sensu orientados para os concursos públicos de nível superior, integrando a preparação para as provas de conhecimento com a titulação - em nível de especialização - para pontuação nas provas de diplomas/ títulos. Ao redor desse elo se desenvolvem os mercados: (a) editorial e gráfico, para a confecção de apostilas, livros, jornais/revistas e sites/blogs especializados em concursos públicos; (b) audiovisual, para a produção de videoaulas; (c) de admissão de instrutores, professores e palestrantes, alguns dos quais se transformam em gurus dos concursos públicos pela sua popularização ancorada em "receitas de sucesso para ser aprovado"; (d) de serviços de inscrições, viagens e hospedagens para a realização dos certames; e (e) de contratação de empresas para elaboração e aplicação das provas, algumas das quais com apelo mercadológico que deturpa a natureza dos processos de seleção. Em números, trata-se de uma cadeia produtiva que movimenta uma cifra estimada em $\mathrm{R} \$ 20$ bilhões/ano, estimulada pela oferta, em média, de 60 mil vagas/ano distribuídas por centenas de concursos públicos pelo país afora que totalizam milhões de inscrições (COELHO, 2018).

Aproveitando-se do imaginário dos brasileiros em torno do emprego público, alimentado pelo sonho por estabilidade, pela ideia de salário garantido e pela alternativa de ocupação em períodos anticíclicos da economia nacional - quando há escassez de postos de trabalho no setor privado e aumenta a taxa de desemprego -, os concursos públicos são divulgados incessantemente pela mídia em chamadas do tipo "Tantas mil vagas previstas para os concursos neste ano" ou "Saíram os editais dos concursos mais esperados neste ano". Tais notícias são acompanhadas de anúncios de empresas de preparação que reforçam a idealização do concurso público como tábua de salvação para a vida profissional e comercializam uma gama de produtos/serviços pertinentes aos certames. De feição caricatural, essa representação social dos concursos públicos é tão arraigada na cultura brasileira, que até o cinema doméstico se baseou nas agruras e vicissitudes enfrentadas pelos candidatos a concursos públicos no país como enredo para uma comédia - o filme O Concurso (2013), dirigido por Pedro Vasconcelos.

A indústria do concurso, apesar de contribuir para a geração de trabalho e renda e a arrecadação de tributos, deixa transparecer um modus operandi que corporifica 
o dogma concurseiro e dilui o ethos do serviço público. Isso, sem citar, outrossim, as aberrações como os pacotes caça-níqueis com supostas "fórmulas mágicas" para a aprovação dos candidatos e - pasmem! - a mercantilização de artefatos como assessoria para elaboração e intercessão incondicional de recursos nos certames.

Aproveitando-se da menção sobre os recursos nos concursos públicos, desvelase a terceira ocorrência, qual seja: a crescente judicialização dos certames (OLIVEIRA, 2017). É até em certa medida compreensível, diante da relevância social da seleção de pessoal no setor público, que surjam muitos litígios na defesa de interesses das partes envolvidas, quais sejam: os candidatos, as instituições organizadoras dos certames e o poder público contratante. Por um lado, sabe-se que parte do processo de judicialização refere-se a controle de legalidade dos certames conduzidos de forma ilícita e/ou que apresentam brechas que ocasionam insegurança jurídica para os candidatos. Essas situações tendem a ser minimizadas, talvez, perante a aprovação da aludida Lei Geral dos Concursos Públicos. Por outro lado, percebemse também exageros em algumas intervenções do Poder Judiciário, do Ministério Público e dos órgãos de Controle Externo nos concursos públicos, configurando ingerências na discricionariedade administrativa do contratante; nesses casos, são típicas as controvérsias em torno dos tipos de provas aplicadas e dos critérios de avaliação utilizados, com o trade-off entre o direito dos candidatos à isonomia e a subjetividade intrínseca a alguns instrumentos qualitativos de aferição de competências pessoais em exames discursivos e práticos.

O fato é que o excesso de interferência das supratranscritas organizações nos concursos públicos no país acaba inibindo a inovação tanto nas formas de elaborar o edital dos certames como nos processos de avaliação dos candidatos. Ou seja, a judicialização, em conjunto com a ideologia concurseira, ergueu uma barreira artificial à inclusão de novas dimensões - tal como a aferição de habilidades e outros atributos - na seleção de pessoal no setor público brasileiro.

Pode-se deduzir que a aflição com o questionamento judicial dos certames arraigou o paradigma da qualificação nos concursos públicos, baseado no domínio simples de conteúdos, em detrimento do modelo de competências que pressupõe a mobilização do conhecimento para a resolução de problemas em determinados contextos - o saber agir/fazer/ser. Extremando o argumento, pode-se conjecturar que, muitas vezes, os cursinhos preparatórios e seus professores ditam socialmente o padrão de provas; as bancas de avaliação, temendo uma enxurrada de recursos, apoiam-se nessas referências, ou mesmo repetem o modelo de provas anteriores, o que torna o formato e o conteúdo das questões bastante previsíveis.

A quarta ocorrência é a secundarização da inteligência de gestão de recursos humanos nos governos e nas organizações públicas. Independente do receio de 
judicialização dos certames, é perceptível a conversão dos editais em um instrumento jurídico por excelência, pouco refletindo sobre as funções e as atribuições do cargo ou emprego em contratação à luz das boas práticas de gestão de recursos humanos no setor público. Em tese, os concursos públicos exitosos em terras brasileiras passaram a ser aqueles que não são judicializados (foco operacional na celeridade temporal e no baixo custo), em vez daqueles que recrutam as pessoas mais bem preparadas para exercerem uma dada atividade (delineamento estratégico para o resultado). Sobre essa proposição, Fontainha et al. (2013, p. 385) corroboram que o instituto jurídico do concurso público no Brasil transformou-se em um fim em si mesmo, “(...) tendo perdido a característica central de meio para alcançar um fim: a seleção da pessoa mais adequada".

Mesmo com a existência de áreas de GRH nas organizações públicas, frequentemente a "palavra final" sobre os concursos públicos é prerrogativa dos departamentos jurídicos, os quais fazem uma análise dos editais do ponto de vista de sua coesão legal e, às vezes, adentram até em proposituras que se coadunam com as exigências das corporações de ofício - como a de direcionar o certame para uma determinada categoria profissional. Cabe ressaltar que a contenda de alguns órgãos de classe em torno dos concursos públicos se, por um lado, combate os privilégios do clientelismo ao exigir certames ilibados para acesso aos cargos e empregos públicos, por outro lado, defende os caprichos do corporativismo nos editais através da reserva de mercado para ingresso em um pool de funções destinadas a alguma(s) profissão(ões). Vale salientar que, assim como o clientelismo, o corporativismo é uma gramática política que fere o universalismo de procedimentos e o ideal republicano. Ademais, no caso em tela, contraria as boas práticas de GRH que recomendam o design de carreiras mais largas e multifuncionais no setor público.

Um exemplo são os concursos públicos de nível superior, cujas funções se referem às atribuições de gestão governamental (áreas funcionais em organizações públicas) e ciclo de políticas públicas (processo de formulação, implementação e avaliação de programas governamentais). A administração pública brasileira em geral - desde a concepção da carreira de EPPGG federal em 1988 - compreende que tal ocupação é dissociada de uma profissão e molda concursos públicos abertos aos profissionais de nível superior nas atividades típicas do ciclo de gestão, com o objetivo de recrutar indivíduos procedentes de diversas áreas de formação acadêmica e, assim, formar equipes de trabalho multidisciplinares para atuarem em programas/projetos transversais. Não obstante, esses concursos públicos sofrem repetidamente - processos de embargo por alguns órgãos de classe que entendem que essas atividades são de direito privativo de sua profissão. Nos níveis federal e estadual, comumente, os órgãos de classe perdem com tal argumentação nos 
processos judiciais, mas, em nível municipal, às vezes, conseguem influir nos editais e até impugnar os certames ${ }^{10}$.

Em outras palavras, o enfoque operacional nos concursos públicos, restrito à praxe do departamento de pessoal, somado aos arroubos corporativistas e à sobreposição da interpretação jurídico-legal à racionalidade administrativogerencial, é uma realidade, sobretudo, em nível subnacional. Em alguns estados e nos municípios de pequeno e médio porte, a ausência de massa crítica para o planejamento dos certames e o foco nas variáveis tempo e custo em sua execução facilitam a sua captura pelos órgãos de classe e incentivam o mimetismo de editais e o copy paste de provas dentro da cultura do "sempre fizemos assim!", como pressupõe o modelo lata de lixo ${ }^{11}$ e/ou configurando-se como uma ação sem reflexão - tal como se fosse uma rotina.

Mesmo em governos e organizações públicas em que a GRH têm uma orientação mais estratégica ou, no mínimo, tática, o modelo de concurso público sofre com a fragmentação entre os processos administrativos de preparação do edital, divulgação do certame para o público, contratação de empresa organizadora, elaboração dos exames, correção das provas, formação inicial dos contratados, acolhimento dos novos funcionários e realização do estágio probatório, ocasionando uma série de distorções no ingresso no serviço público. O desalinhamento entre os subsistemas de planejamento da força de trabalho, seleção de pessoal, alocação funcional e gestão do desempenho no estágio probatório são per si falhas na GRH no setor público advindas da falta de coordenação de suas tarefas que se autonomizam erroneamente - em rotinas funcionais inertes, herméticas e incomunicáveis. Essas

\footnotetext{
${ }_{10}$ Um exemplo hodierno de medida antiquada oriunda da defesa institucional de uma corporação de ofício é o Projeto de Lei do Senado no 439/2015. Em tramitação, esse PLS " (...) estabelece que cargos e funções com atribuições voltadas para os campos da Administração, em organizações privadas, não governamentais e públicas, somente poderão ser providos por Tecnólogos e Administradores profissionais regulares na forma da lei, que ficam obrigados a comprovar, anualmente, perante organização empregadora, a regularidade com o Conselho Regional de Administração - CRA". Com chances remotas de aprovação até pela sua divergência com a prática social da gestão empresarial e mesmo da gestão pública, o teor do PLS denota per si o enlevo corporativo.

${ }^{11} \mathrm{O}$ modelo lata de lixo ou garbage can, desenvolvido por Cohen, March e Olsen (1972), interpreta que a tomada de decisão organizacional é feita como se as alternativas estivessem em uma lata de lixo. Neste caso, as soluções não seriam detidamente analisadas e dependeriam do leque de soluções que os gestores possuem no momento. Logo, a compreensão do problema e das soluções é limitada, e as organizações acabam por operar em um sistema de tentativa e erro. No limite, o modelo subentende que soluções procuram por problemas. No caso do instituto jurídico do concurso público no Brasil, esse modelo reflete as falhas de inteligência na GRH no setor público, sobretudo nos pequenos e médios municípios. Diante de gaps de capacidade administrativa nas prefeituras, órgãos de classe e conselhos profissionais ofertam para os prefeitos e secretários municipais kits de concursos públicos com editais e provas sem custo financeiro, mas com um aprisionamento, qual seja: os editais preveem reserva de mercado para uma profissão e/ou as provas são pautadas em conteúdos programáticos típicos da formação acadêmica de uma determinada categoria profissional.
} 
falhas se somam à secundarização da inteligência de $\mathrm{GRH}$ e retroalimentam o círculo vicioso do modelo de concurso público no Brasil, alentando a insuficiência ou ausência de um ethos de serviço público. A Figura 1 ilustra essa interpretação do círculo vicioso sobre os concursos públicos no país.

Figura 1 - Círculo vicioso do modelo atual de concurso público no Brasil
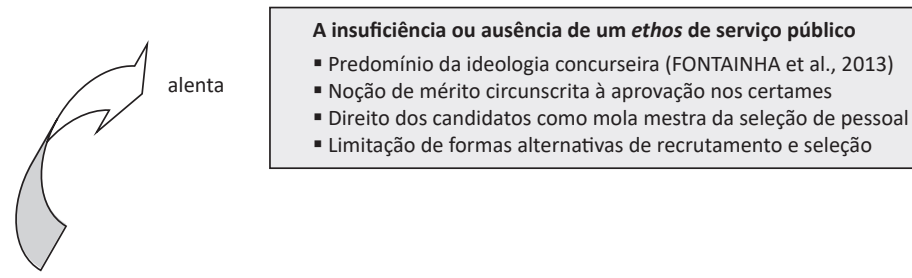

A insuficiência ou ausência de um ethos de serviço público

- Predomínio da ideologia concurseira (FONTAINHA et al., 2013)

- Noção de mérito circunscrita à aprovação nos certames

- Direito dos candidatos como mola mestra da seleção de pessoal

- Limitação de formas alternativas de recrutamento e seleção

A Secundarização da inteligência de GRH

- Edital como instrumento jurídico sem apelo e reflexão gerencial

- Falta de massa crítica na gestão de pessoas no setor público

- Foco exacerbado nas variáveis tempo e custo nos certames

- Desalinhamento entre as etapas dos concursos públicos

A indústria do concurso público

- Corporificação do dogma concurseiro

- Concurso público como tábua de salvação profissional

- Imaginário/sonho do emprego estável e salário garantido

- Mercantilização de artefatos e incentivo aos recursos nos certames

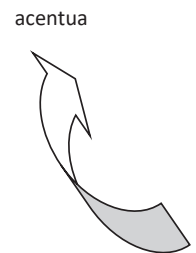

A judicialização crescente dos certames

- Relevância social dos concursos e aumento dos litígios

- Ingerência na discricionariedade administrativa do contratante

- Inibição à inovação nas formas de avaliação dos candidatos

- Manutenção do paradigma de qualificação nos certames

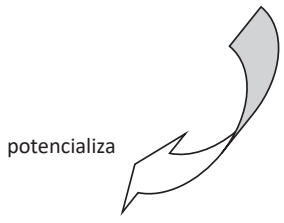

Fonte: adaptado de Coelho (2015, p. 77).

Dos quatro aspectos fáticos que conformam tal círculo vicioso, a secundarização de inteligência da GRH no setor público do país - e suas falhas - são aprofundadas a seguir, abordando-se a defasagem do modelo vigente de concursos públicos e a desintegração entre os subsistemas de gestão de recursos humanos relacionados com o ingresso nos governos e/ou organizações públicas.

\section{O anacronismo do modelo vigente de concurso público no Brasil}

Um retorno às origens do concurso público relaciona, inexoravelmente, a adoção desse instituto com os esforços de implantação do modelo burocrático, de inspiração weberiana, cujos princípios de impessoalidade, formalismo e meritocracia engendram procedimentos de racionalização para a entrada no serviço público como um antídoto contra as práticas patrimonialistas. Fenômeno típico do 
século $20^{12}$ em diversos países, o surgimento dos primeiros certames traduzia os ideais de uma administração pública racional-legal em uma política de recursos humanos macrogovernamental ou, no mínimo, em diretrizes oficiais para a seleção de pessoal em algumas áreas do setor público.

No Brasil, o despontar dessa história é amplamente conhecido; refere-se à reforma administrativa do Departamento Administrativo do Serviço Público (Dasp), no âmbito do Governo Vargas, na década 1930. Surgem, na ocasião, as primeiras carreiras burocráticas com acesso por concurso público no Governo Federal, mas o alcance é limitado a alguns órgãos. Como afirma Bresser-Pereira (1995) em seu diagnóstico da gestão pública nacional para o Plano Diretor da Reforma do Aparelho do Estado:

No que diz respeito à administração de pessoal, o DASP representou a tentativa de formação da burocracia [na administração pública federal], baseada no mérito profissional. Entretanto, embora tenham sido valorizados instrumentos importantes, tais como o concurso público e o treinamento, não se chegou a adotar consistentemente uma política de recursos humanos que respondesse às necessidades do Estado. O patrimonialismo, embora em processo de transformação, mantinha ainda sua própria força no quadro político brasileiro. O coronelismo dava lugar ao clientelismo e ao fisiologismo (BRESSER-PEREIRA, 1995, p. 19).

Juridicamente, o instituto do concurso público é previsto no país desde a Constituição de 1934. Na oportunidade, em contrapartida ao sistema discricionário de contratação de funcionários públicos, em vigor desde o Império e de legado colonial, é legislado o provimento de cargos públicos sob os auspícios da igualdade e da imparcialidade. O artigo 168 da CF de 1934 reconhecera que: "os cargos públicos são acessíveis a todos os brasileiros, sem distinção de sexo ou estado civil, observadas as condições que a lei estatuir". E, complementando, o artigo 170 afirmara que: "a primeira investidura nos postos de carreira das repartições administrativas, e nos demais que a lei determinar, efetuar-se-á depois de exame de sanidade e concurso de provas e títulos" (SOUSA, 2011).

As Constituições Federais de 1937 e 1946, com alguns ajustes, conservaram a compreensão da CF de 1934 sobre os concursos públicos, e a aplicação de tal instituto no país ocorreu à luz de um modelo burocrático incompleto,

\footnotetext{
12 Embora o instituto do concurso público se espraie no século 20 , suas raízes remontam ao século 19 e se coadunam com o Estado de Direito e o princípio da igualdade nas relações jurídicas civis em países como França e Estados Unidos. O objetivo era diminuir as condições particularísticas de privilégios na admissão de funcionários públicos, tais como a hereditariedade, o nepotismo, a compra/venda e arrendamento de cargos e a nomeação pela patronagem que marcou as monarquias absolutistas.
} 
no qual o uso dos cargos de livre provimento se tornou regra e não exceção, impulsionado pela patronagem e pelo nepotismo. Não obstante, os certames, quando utilizados pela administração pública brasileira - sobretudo, em nível federal e estadual -, eram aderentes ao paradigma de recursos humanos no setor público da época, a saber: predomínio de cargos (sem estruturas de carreiras), ênfase na especialização funcional com design ocupacional estreito, vinculação institucional verticalizada, associação entre ocupação e profissão, abordagem da qualificação com viés conteudista, desenvolvimento profissional atrelado aos critérios de antiguidade e conformidade, foco em valores coletivos (esprit de corps) da burocracia, entre outros.

Na sequência, as Constituições Federais de 1967 e 1988 ${ }^{13}$, independente das várias alterações no regramento sobre ingresso nos cargos públicos e nos empregos públicos, mantiveram as características do instituto do concurso público, cuja prática contemporânea preservou a diretriz/visão tradicional de gestão de pessoas na administração pública. Embora se observem inovações gerenciais em concursos públicos de diferentes níveis de governo e em uma variedade de organizações públicas do país nos últimos 20 anos, percebe-se - em larga escala - uma defasagem dos certames em relação aos novos ditames da gestão de recursos humanos no setor público, quais sejam: ingresso em carreiras, espaço de atuação largo e atribuições multitarefas, vinculação institucional mais ampla e maior mobilidade interorganizacional, dissociação de uma única profissão e escopo profissiográfico generalista, abordagem de competências técnicas e gerenciais, desempenho individual na função como critério de promoção, orientação pelo ethos de serviço público etc. Logo, como os concursos públicos moldados por essas características são, de maneira patente, a minoria no país nos dias correntes, pode-se intuir que o processo de seleção de pessoal no setor público brasileiro padece de uma condição de obsolescência.

De uma perspectiva mais abrangente, esse descompasso entre a práxis do concurso público no Brasil e os pressupostos das transformações recentes da gestão de pessoas no setor público - descritos por Longo (2007) pelo binômio mérito e flexibilidade - é revelador do arraigamento da concepção de profissionalização na administração pública do país apenas pela noção clássica de mérito. Dito de outra maneira, estamos enclausurados no ideário fundante de profissionalização da administração pública que condiciona a sua existência exclusivamente ao grau de institucionalização da burocracia pelos moldes weberianos, dentro da tradição de formação de corpos profissionais permanentes e estáveis que têm como normativa a dicotomia entre política e administração.

\footnotetext{
${ }^{13}$ Para um compêndio sobre o instituto do concurso público no Brasil nas diversas Constituições Federais do país, ver o capítulo 1 (p. 23-30) da dissertação de mestrado de Sousa (2011).
} 
Sem querer negar a importância histórica e basilar dessa referência para o avanço do modelo organizacional do setor público em direção aos valores republicanos, no cenário do final dos anos 1990 e início do século 21 assiste-se a uma ressignificação, diante do movimento de Reforma do Aparelho do Estado, da profissionalização da administração pública, com a perda de exclusividade do paradigma burocrático e a ampliação de sua acepção na esteira do debate sobre desempenho governamental. Desse prisma, gestão por resultados, responsividade e accountability são algumas das premissas que acondicionam a flexibilidade como uma categoria para se (re) pensar o entendimento sobre o que é profissionalização no setor público, com reflexos nos instrumentos de GRH em geral, e nas formas de recrutamento e seleção em particular (PACHECO, 2010).

No Brasil, porém, como discutido na subseção anterior, a ideologia concurseira tolhe um maior desenvolvimento dessa matriz. É premente nos anos vindouros uma reformulação do instituto do concurso público no país vis-à-vis as tendências estruturais do Estado brasileiro e os novos imperativos da GRH no setor público, ligando o conceito de profissionalização também com a capacidade de prestação de melhores serviços públicos para a sociedade. Enfim, o desafio é a construção de um olhar sobre os concursos públicos que não se restrinja à função de constituição de uma burocracia estatal pela garantia dos direitos individuais e com o objetivo único de proteção do funcionalismo público de ações arbitrárias dos políticos. A questão central é como (re)conectar substantivamente os anseios de mérito ao propósito de alcance de resultados na ação estatal.

\section{A desintegração entre os subsistemas de ingresso no serviço público}

À defasagem do modelo atual de concurso público no país, soma-se a desintegração entre os subsistemas de GRH atinentes ao ingresso no serviço público, resultante do velho enfoque operacional do departamento de pessoal na administração pública - pela persistente desvalorização da atividade-meio de gestão de pessoas -, que fragmenta demasiadamente as suas funções e processos.

O argumento central deste ensaio é de que o problema da desatualização do modelo corrente de concurso público no Brasil, em parte explicado por disfunções como a ideologia concurseira, adicionado ao problema de desalinhamento entre as etapas de desenho do certame, seleção de pessoal, integração dos aprovados e a avaliação de desempenho dos novos funcionários públicos, acarretam distorções no ingresso no serviço público do Brasil. A Figura 2 esboça esse esquema de desintegração da GRH. 
Figura 2 - Subsistemas de GRH desintegrados no ingresso no serviço público

Recrutamento \& Seleção

(maneiras de divulgação, perfil dos candidatos e formas de avaliação)

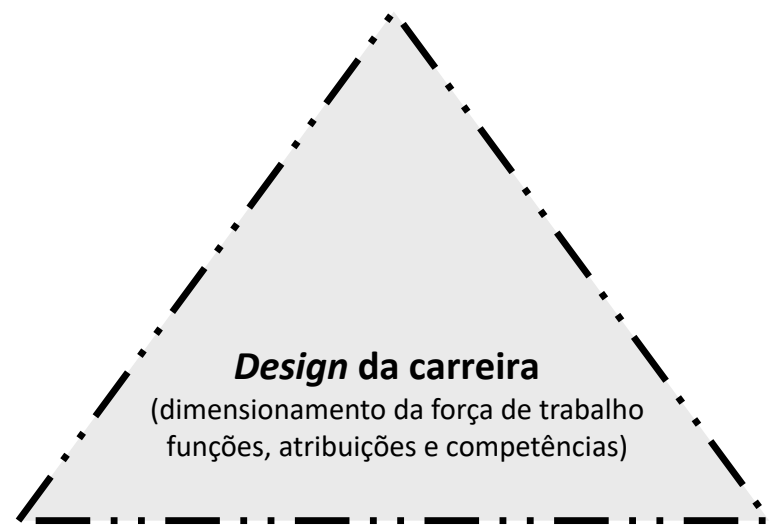

\section{Admissão funcional}

(acolhimento, alocação e capacitação)
Gestão do desempenho

(monitoramento e estágio probatório)

Fonte: adaptado de Coelho (2015, p. 82).

A ideia do arquétipo é que, em vez de uma integração entre os subsistemas de GRH no ingresso no serviço público, verifica-se uma desintegração, com a falta de pontos de contato entre as práticas de gestão de recursos humanos concernentes aos concursos públicos, configurando uma cadeia composta de elos perdidos. É relativamente fácil encontrar casos de certames pelo país afora em que as atividades/tarefas dos subsistemas de ingressos são fragmentadas entre si, evidenciando descoordenações, incoerências e inconsistências. ${ }^{14}$

Parailustrara supramencionada desintegração sugerida pela Figura 2, imaginemos um concurso público para um cargo de analista de gestão governamental em que o edital, mais preocupado com as questões formais, não aprofunda a descrição das funções/atribuições profissionais. O edital, então, é divulgado, e dada a sua pouca precisão profissiográfica, acaba atraindo uma grande quantidade de candidatos que se preparam para outros certames, fora do perfil almejado. Considerando também o tempo exíguo para a realização do certame e as falhas de diálogo nesse ínterim entre o órgão contratante e a instituição terceirizada para a elaboração/aplicação das provas, a abordagem e o conteúdo dos exames não conseguiram refletir com certa fidedignidade o padrão avaliativo esperado pela organização pública. Na sequência, após a realização do concurso e a convocação dos aprovados, suponha

\footnotetext{
${ }^{14}$ Para um overview do esboço original de um modelo analítico de fragmentação na gestão pública brasileira, ver a tese de doutorado de Martins (2003).
} 
que os indivíduos que tomaram posse iniciam a sua entrada no serviço público desprovidos de um processo de acolhimento e sem a devida orientação para a iniciação nas atividades laborais.

Alguns meses mais tarde, após a desistência de vários profissionais recémadmitidos por diversos motivos (aprovação em outros certames, não adaptação à função, falta de clareza sobre o horizonte da carreira etc.), os funcionários remanescentes são convocados para um programa de treinamento na escola de governo que tem pouca equivalência com o trabalho presente e as perspectivas de atividade futura do cargo. Pouco tempo depois do término dessa capacitação, mesmo a unidade de $\mathrm{RH}$ já tendo um mapa das competências individuais de várias pessoas que estão na carreira, mantém-se a distribuição delas nas áreas originais, desenvolvendo o mesmo tipo de trabalho; em alguns casos, com ausência de supervisão e totalmente deslocadas das equipes de trabalho.

$\mathrm{E}$, finalmente, passados mais de dois anos e meio da posse, restando menos de seis meses para o final do estágio probatório, nenhum processo de avaliação de desempenho mais substancial, além das formalidades habituais, foi realizado. $A$ maioria dos funcionários já se acostumou ao standard burocrático, à inexistência de mecanismos de incentivos/sanções e à falta de liderança. O ambiente organizacional na repartição pública é de desmotivação e baixa performance.

Guardadas as devidas proporções e sem a pretensão de esboçar um estereótipo, a descrição acima se amolda a um farto número de concursos públicos realizados em território nacional. E engana-se quem acredita que esses problemas ocorrem tão somente em concursos públicos destinados ao preenchimento de cargos na burocracia operacional - como os certames de nível médio. Em muitos processos de recrutamento e seleção de carreiras estratégicas que perfazem a burocracia de médio escalão são visíveis também a falta de zelo e de acuracidade gerencial, conforme demonstram Moraes e Coelho (2018). Trata-se de um quadro contextual anormal que está naturalizado na GRH no serviço público e que necessita ser repensado no âmbito das políticas públicas de gestão no Estado brasileiro.

\section{Considerações finais}

Nos últimos 30 anos, a partir do arcabouço legal da Constituição Federal de 1988, o Brasil vivenciou um ciclo de (re)estruturação da função pública marcado por reformas e inovações administrativo-institucionais que abarcaram todas as áreas funcionais da gestão pública, incluindo a GRH. A construção de uma burocracia pública - ou serviço civil - competente no país nesse intervalo de tempo experimentou diversos avanços que amalgamaram ideais weberianos de 
profissionalismo com princípios da New Public Management, como flexibilidade e gestão por resultados. Cita-se, a título de ilustração, a criação e consolidação de carreiras largas de Estado e a retomada da capacitação - sob a égide do conceito de escolas de governo - na União, em muitos estados e em alguns municípios desde meados dos anos noventa ${ }^{15}$. Não obstante, são inúmeros os dilemas nos últimos anos na área de gestão de pessoas na administração pública nacional, agravados com as crises ético-política e econômico-fiscal.

Em adição às contendas econômicas sobre a gestão das despesas não financeiras de gastos com pessoal e a previdência dos servidores públicos, temos uma miríade de problemas organizacionais na GRH no setor público brasileiro como: a hegemonia da visão jurídica no gerenciamento, a debilidade de abordagens estratégico-táticas nos departamentos de pessoal setoriais e unidades centrais de recursos humanos (UCRHs), a falta de uma política integrada de recursos humanos nos governos e crescentes disfunções gerenciais nos diversos subsistemas de $\mathrm{GRH}^{16}$. Seria o fim de um ciclo? Quais são as novas bases e parâmetros para reorganizar essa discussão e as práticas de gestão de pessoas no Estado? ${ }^{17}$

No bojo dessa problemática atual da GRH nos governos tem surgido um movimento pró-pessoas na agenda pública, interpenetrando comunidades de práticas de gestores públicos e organizações do terceiro setor - neste caso, ONGs e Institutos e Fundações Empresariais. Por um lado, iniciativas como essa têm colaborado na evidenciação da GRH como determinante do desempenho da administração pública, um desafio de longa data da gestão de pessoas no âmbito governamental. Mas, por outro lado, podem fomentar modas e modismos de gestão de pessoas como panaceia para resolver problemas - o chamado Pop Public Management ${ }^{18}$, baseado em 'programas de sete passos' ou receituários que desconsideram, por vezes, variáveis do sistema político e as capacidades estatais. Enfim, o ponto central é como avançar em direção a uma macropolítica

\footnotetext{
${ }^{15}$ Para um compêndio dos esforços realizados no Governo Federal em prol da construção de uma política de recursos humanos na segunda metade da década de 1990, ver Ministério do Planejamento (2002). E para uma análise crítica das tentativas de se caminhar para uma gestão estratégica de recursos humanos no Governo Federal, a partir da Política Nacional de Desenvolvimento de Pessoal (2006), ver a dissertação de mestrado de Camões (2013).

${ }^{16}$ Gaetani (2018), em artigo de opinião no Valor Econômico, sumariza de forma primorosa algumas evidências do corporativismo de estamentos burocráticos no Governo Federal e algumas disfunções na gestão pública como paralisias e graves déficits de capacidade administrativa (incluindo de pessoal).

${ }_{17}$ Um balanço inicial dessa problemática atual da GRH encontra-se no working paper de Levy e Coelho (2018), intitulado The end of a cycle: 30 years of civil service reforms in Brazil.

${ }^{18}$ Em alusão ao fenômeno Pop Management, analisado em um artigo de Thomaz Wood Jr. e Ana Paula Paes de Paula para a gestão empresarial - apresentado e publicado nos anais do EnANPAD, em 2001.
} 
estratégica de gestão do capital humano na administração pública que: possua legitimidade para enfrentar as pressões da patronagem; tenha governabilidade para suplantar o recrudescimento do corporativismo burocrático; e seja coordenada no nível macrogovernamental. Temos uma janela de oportunidade para uma profunda reforma administrativa na GRH nos anos vindouros ou a fragmentação do contexto político corrente permite tão somente alguns ajustes/ mudanças graduais? Eis a questão.

Algumas reformas na gestão de pessoas no setor público brasileiro, pela interdependência entre a doutrina do direito administrativo e as inovações nas práticas de gerenciamento, são per si wicked problems. Acrescenta-se que a política de recursos humanos nos governos, pela dispersão de carreiras (mais de 300 no Governo Federal, por exemplo) e os distintos poderes de barganha de cada ator burocrático, configura-se como de natureza redistributiva e com arena altamente conflitiva ${ }^{19}$.

Em relação ao ensaio - o concurso público como proxy das disfunções na GRH no serviço público -, considerou-se a dependência da trajetória da lógica jurídica e da abordagem operacional (DP) na gestão de pessoas no governo e nas organizações públicas, para representar os entraves e reptos que perpassam todos os subsistemas de recursos humanos. O texto revisitou o instituto do concurso público no país e jogou luz em algumas de suas anomalias nos dias correntes, desvelando um círculo vicioso. $E$, adicionalmente, sob o argumento de secundarização da inteligência de $\mathrm{GRH}$, discutiu-se a desatualização do modelo de concurso público vigente, bem como os efeitos danosos advindos da fragmentação entre as etapas dos certames. Em resumo, dois problemas de ordem gerencial que ocasionam distorções no ingresso no serviço público.

Cumpre comentar que uma limitação natural deste ensaio é a análise detida em alguns elementos intraorganizacionais em detrimento do caráter multifacetado da GRH e sem abranger os aspectos políticos mais amplos que influenciam o sistema de recursos humanos no setor público. Ademais, não exploramos a literatura internacional de gestão de pessoas em governos e tampouco recorremos a alguma análise comparada com países que se utilizam - tradicionalmente - do sistema de meritocracia baseado no instituto do concurso público.

Como implicações gerenciais para a modernização da seleção de pessoal no setor público brasileiro, bem como para uma agenda de inovações no instituto do concurso público no país, alicerçadas na $\mathrm{GRH}$, apontam-se algumas recomendações, a seguir.

\footnotetext{
${ }^{19}$ Para uma adaptação da tipologia de políticas públicas de Lowi na área-meio de gestão de pessoas no setor
} público, ver a dissertação de mestrado de Débora Muzzi, apresentada ao ISG/Lisboa, em 2014. 
- Na administração pública federal (APF) e nos governos estaduais, considerando a descentralização da função de recursos humanos entre as diversas áreas (ministérios ou secretarias) e as várias organizações públicas, incluindo a administração indireta, é bem-vindo se realizar uma radiografia dos concursos públicos feitos nos últimos 20 anos, analisando seus processos e resultados. Esse é um papel da(s) área(s) de gestão/planejamento governamental e da unidade central de recursos humanos, com o objetivo de identificar as good practices (na União, por exemplo, um benchmark é o Banco Central) e, com base em tais referências, elaborar uma carta de serviços para instruir os RHs setoriais no design e na organização de certames. Tal processo pode e deve ser suplementado com a capacitação dos gestores de $\mathrm{RH}$ no tópico de concursos públicos pelas escolas de governo.

- No tocante aos municípios, nível de governo no qual a capacidade estatal é inferior, abarcando a função de GRH, sugere-se estruturar um programa federal e/ou estadual de apoio à gestão pública que englobe a política de recursos humanos e o instituto do concurso público.

- Em todos os níveis de governo (e nas organizações públicas), é fundamental que a importância que se atribui aos concursos públicos para a alta e média burocracia se estenda para os certames voltados para a street level bureaucracy e o corpo burocrático operacional. Muitas vezes, a GRH não trata os concursos públicos de nível médio, por exemplo, com o devido zelo e acuracidade, acentuando algumas disfunções como a sobrequalificação.

- E deve-se estimular a integração dos processos administrativos das fases do concurso público com as etapas do pós-concurso como componentes de um sistema de ingresso. O recrutamento e a seleção pelo concurso público abarcam: a constituição da comissão do certame; a elaboração e divulgação do edital; a contratação, elaboração e aplicação da(s) prova(s); e a realização de cursos de formação específicos previstos como etapa de seleção ou classificação dos candidatos. Já o pós-concurso público, por sua vez, compreende tanto a realização de programas de integração como a alocação laboral dos funcionários. Iniciado o exercício profissional, inaugura-se o triênio do estágio probatório, englobando as avaliações de desempenho, prováveis atividades de capacitação, possíveis realocações de funcionários entre áreas e a efetivação (ou não) no cargo/emprego no final do período. Idealmente, essas fases/etapas devem ser alinhadas pela GRH (MORAES; COELHO, 2018).

- E é fulcral incentivar o experimentalismo de processos de recrutamento e seleção alternativos, baseados na flexibilidade, como contratos de trabalhos e formas de ocupação de cargos de livre-provimento (DAS) baseadas em 
seleções abertas que tenham critérios de avaliação explícitos pautados em competências desejáveis aos postos de trabalho.

Finalizando, vale uma comparação entre o instituto do concurso público e o instituto das compras públicas no Brasil. Embora existam incontáveis críticas à Lei de Licitações, é notório que o sistema de compras governamentais se modernizou - incrementalmente - no Brasil, na última década, com o aporte de tecnologias de informação (e-gov) nas aquisições públicas e o aumento da intelligentsia na gestão de cadeias de suprimentos nos governos. É essa modernização verificada no sistema de contratação de bens e serviços do Estado brasileiro que se espera que ocorra no processo coirmão de contratação de pessoal, compreendendo o instituto do concurso público e os modelos de admissão alternativos.

Contudo, é digno de nota o quão crucial é a aproximação entre os gestores públicos e os juristas no debate sobre a modernização do instituto do concurso público no Brasil. De outro modo, se não houver uma ambiência para o diálogo entre esses dois atores da elite burocrática em tal temática, corre-se o risco da permanência de uma incompreensão mútua, na mesma linha em que Nohara (2012) atesta os conflitos interpretativos entre os gestores públicos e os juristasadministrativistas durante a gestação do modelo de administração pública gerencial a partir do Plano Diretor de Reforma do Aparelho do Estado (PDRAE) em 1995.

Melhor dizendo, é de suma importância a concertação entre os diversos stakeholders do poder público que gravitam em torno do instituto dos concursos públicos - órgãos de gestão/planejamento, unidade central de recursos humanos, departamentos setoriais de $\mathrm{RH}$, negócios jurídicos, casas legislativas e órgãos de controle externo, Poder Judiciário e Ministério Público -, para a construção de caminhos para a (re)calibragem do arcabouço legal com as ferramentas gerenciais que possibilitem a inovação nesse modelo de recrutamento e seleção pessoal. ${ }^{20}$

\section{Referências bibliográficas}

ABRUCio, F. L. Reforma do Estado no federalismo brasileiro: a situação das administrações públicas estaduais. Rev. Adm. Pública, Rio de Janeiro, v. 39, n. 2, mar./abr. 2005. Disponível em: < http://bibliotecadigital.fgv.br/ojs/index.php/rap/article/ view/6576/5160>. Acesso em: 26 jun. 2018.

\footnotetext{
${ }^{20}$ Um exemplo cabal, em nível federal, dos conflitos entre política e administração e das controvérsias entre controle e gestão em torno da inovação no modelo de concurso público, foi o cancelamento do certame para a carreira de EPPGG, durante a realização da segunda fase, em 2013. Para as altercações entre Ministério do Planejamento (MP), Anesp e TCU nesse concurso público, ver o relato do MP em: http://www.planejamento.gov. br/assuntos/gestao-publica/noticias/ministerio-do-planejamento-esclarece-concurso-de
} 
AlBRECHT, P. A.; KRAWULSKI, E. Concurseiros e a busca por um emprego estável: reflexões sobre os motivos de ingresso no serviço público. Cadernos de Psicologia Social do Trabalho, São Paulo, v. 14, n. 2, p. 211-226, dez. 2011.

BResser-PereirA, L. C. Plano diretor da reforma do aparelho do Estado. Brasília, DF: Presidência da República do Brasil: Câmara da Reforma do Estado, 1995.

Carvalho Filho, J. S. Manual de direito administrativo. Rio de Janeiro: Editora Lúmen Júris, 2007.

CAMÕES, M. R. S. Análise do processo de implementação da Política Nacional de Desenvolvimento de Pessoal. Dissertação (Mestrado em Administração) - FACE, Universidade de Brasília, Brasília, 2013.

COELHO, F. S. Repensando os concursos públicos no Brasil: subsídios para discussão à luz da gestão de pessoas no setor público. In: BASSOTTI, I.; PINTO, S.; SANTOS, T. (Orgs.). Uma nova gestão é possível. 1. ed. São Paulo: Edições Fundap, 2015.

CoElHo, F. S. Crise faz crescer procura pelos concursos públicos: levantamento aponta que 162 mil vagas devem ser abertas neste ano, mas especialistas acreditam que faltam recursos para contratações efetivas. Bom Dia Brasil (Programa de TV). São Paulo, 8 de janeiro, 2018. Disponível em: <https://globoplay.globo. $\mathrm{com} / \mathrm{v} / 6405739 />$

COHEN, M.; MARCH, J.; OLSEN, J. A garbage can model of organizational choice. Administrative Science Quarterley, 1972.

FonTAINHA, F. C. et al. Processos seletivos para a contratação de servidores públicos: Brasil, o país dos concursos? In: BRASIL. Ministério da Justiça. Secretaria de Assuntos Legislativos. Mecanismos jurídicos para a modernização e transparência da gestão pública. Brasília, DF, 2013. (Série Pensando o Direito, n. 49). v. 1, p. 293-298.

GAETANI, F. A governabilidade da administração em jogo. Valor Econômico, 20 abr. 2018. Disponível em: <https://www.valor.com.br/opiniao/5468781/governabilidade-da-administracao-em-jogo>. Acesso em: 16 mai. 2018.

Instituto Brasileiro de Geografia e Estatística (IBGE). Pesquisa de Informações Básicas Municipais - MUNIC. Rio de Janeiro: IBGE, 2015.

Instituto Brasileiro de Geografia e Estatística (IBGE). Pesquisa de Informações Básicas Estaduais - ESTADIC. Rio de Janeiro: IBGE, 2015.

LAMELO, T. M. et al. Processo seletivo público para escolha de secretário municipal: análise da experiência da cidade de Londrina, PR. RACE - Revista de Administração, Contabilidade e Economia, [S.I.], p. 235-258, dez. 2017. ISSN 2179-4936. Disponível em: <http://editora.unoesc.edu.br/index.php/race/article/view/15106>. Acesso em: 10 Abr. 2018.

LeVy, E.; CoElho, F. S. The end of a cycle: 30 years of civil service reforms in Brazil. In: World CONGResS OF Political SCIENCE, 25., 2018, Brisbane. IPSA Online Paper Room, 2018.

LeVy, E.; Coelho, F. S; Menon, I. O. Avanços, dilemas e desafios na construção de uma burocracia competente: gestão de pessoas no Congresso Consad (2008 2016). In: Congresso ConSAD de GeStÃo PúBliCA, 10., 2017, Brasília. Disponível em: 
https://drive.google.com/open?id=1JmcDaG12SQ39QfvDXp_iqHvN9V18It-2. Acesso em 02 set 2018.

LoNGo, F. Mérito e flexibilidade: a gestão de pessoas no setor público. São Paulo: Edições Fundap, 2007.

LOTTA, G. S. Implementação de políticas públicas: o impacto dos fatores relacionais e organizacionais sobre a atuação dos burocratas de nível de rua no Programa Saúde da Família. 2010. Tese (Doutorado em Ciência Política) - Faculdade de Filosofia, Letras e Ciências Humanas, Universidade de São Paulo, São Paulo, 2010.

MAIA, M. B.; QUEIROZ, R. P. O regime jurídico do concurso público e o seu controle jurisdicional. São Paulo: Editora Saraiva, 2007.

MARCONI, N. Políticas integradas de recursos humanos para o setor público. In: LEVY, E; Drago, P. A. (Orgs.). Gestão pública no Brasil contemporâneo. São Paulo: Edições Fundap, 2005. p. 330-348.

MARTINS, H. F. Uma teoria da fragmentação de políticas públicas: desenvolvimento e aplicação na análise de três casos de políticas de gestão pública. Tese (Doutorado em Administração) - Escola Brasileira de Administração Pública e de Empresas, Fundação Getulio Vargas, Rio de Janeiro, 2003.

MeIrelles, H. L. Direito Administrativo brasileiro. São Paulo: Editora Malheiros, 1999.

Merton, R. K. Social theory and social structure. Nova York: Free Press, 1959.

Ministério do Planejamento (MPOG). A Política de Recursos Humanos na Gestão FHC. Brasília: Seges, 2002.

Ministério do Planejamento (MPOG). Boletim Estatístico de Pessoal. Brasília: MPOG, 2015.

MORAES, L. L.; COELHO, F. S. (Des)integração entre os subsistemas de ingresso no serviço público: análise de uma carreira do ciclo de gestão. Cadernos Gestão Pública e Cidadania, v. 23, n. 75, p. 284-308, mai.-ago. 2018. Disponível em: <http://bibliotecadigital.fgv.br/ojs/index.php/cgpc/article/view/76877/73727>. Acesso em: 1 set. 2018.

Muzzı, D. Tipologia de políticas públicas: uma proposta de extensão do modelo de Lowi (para a gestão de pessoas no setor público). Dissertação (Mestrado em Gestão Pública) - Escola de Gestão, ISG, Lisboa, 2014. Disponível em: < https://comum. rcaap.pt/bitstream/10400.26/7097/1/Disserta\%C3\%A7\%C3\%A3o_D\%C3\%A9bora_Muzzi.pdf> Acesso em: 24 mai. 2018.

NOHARA, I. P. Reforma administrativa e burocracia: impacto da eficiência na configuração do direito administrativo brasileiro. São Paulo: Editora Atlas, 2012.

OlıveırA, L. A. A judicialização do concurso público. Site Conteúdo Jurídico, Brasília, 3 de julho de 2017 (artigo de opinião).

OMURO, L., PEREIRA, M., PINTO, S. Recrutamento e seleção: um novo processo é possível. In: BASSOTTI, I.; PINTO, S.; SANTOS, T. (Orgs.). Uma nova gestão é possível. 1. ed. São Paulo: Editora Fundap, 2015. 
PACHECO, R. S. Profissionalização, mérito e proteção da burocracia no Brasil. In: Abrucio, F.; LoUReIRo, M. R.; PACHeCo, R. S. (Org.). Burocracia e política no Brasil: desafios para o Estado democrático no século XXI. Rio de Janeiro: FGV, 2010. p. 233-255.

RODRIGUES, A. L. et al. O trabalho e seus sentidos: um estudo com peritos criminais da Polícia Federal. Rev. Adm. Pública, Rio de Janeiro, v. 51, n. 6, p. 1058-1084, nov.-dez. 2017. Disponível em <http://www.scielo.br/scielo.php?script=sci_arttext\&pi$\mathrm{d}=$ S0034-76122017000601058\&lng=pt\&nrm=iso>. Acessos em: 3 Mar. 2018.

SousA, A. R. O processo administrativo do concurso público. 2011. Dissertação (Mestrado em Direito Público) - Faculdade de Direito, Universidade Federal de Uberlândia, Uberlândia, 2011.

Wood JR., T., PAES De PAULA, A. Pop Management. In: Encontro de Administração da Anpad, 25., 2001, Campinas. Anais... Campinas: Anpad, 2001.

\section{Fernando de Souza Coelho}

Doutor em Administração Pública e Governo pela Escola de Administração da Fundação Getúlio Vargas de São Paulo (FGV-SP). Atualmente é docente da Escola de Artes, Ciências e Humanidades da Universidade de São Paulo (USP), no Curso de Graduação em Gestão de Públicas e no Programa de Mestrado em Gestão de Políticas Públicas. Contato: fernandocoelho@usp.br

\section{Isabela de Oliveira Menon}

Mestre em Gestão de Políticas Públicas pela Escola de Artes, Ciências e Humanidades da Universidade de São Paulo (EACH-USP). Atualmente trabalha na Secretaria Municipal de Gestão de São Paulo e atua como pesquisadora no Lab.Gov - Laboratório de Gestão Governamental, da USP. Contato: isaom@usp.br 